\title{
Review of postharvest rice straw use: change in use and the need for sustainable management policies in Vietnam
}

\author{
Tổng quan việc sử dụng rơm rạ sau thu hoạch: Thay đổi trong sử dụng và cần chính sách \\ quản lý bền vững ở việt Nam \\ NGUYEN, Trung Dung $1,2 *$ \\ 'Sustainable Development Consulting Corporation, Ltd., Suite 803 A, Golden Land Building, 275 Nguyen Trai St., Thanh Xuan Dist., Hanoi, \\ Vietnam; ${ }^{2}$ Faculty of Agricultural and Environmental Sciences, Universität Rostock, SUVALIG Research Project Team, Justus-von-Liebig-Weg 6, \\ 18059 Rostock, Germany
}

\begin{abstract}
Annually, about 40-60 million tons of postharvest straw are generated in Vietnam. Although considered as renewable resources and economic goods, straw is still burned in the field because there is no longer needed for cooking, roofing and fodder as before 1990s. The general economic development of the country and the rural area changed all the previous practices of using straw. This paper analyzes the socio-economic and technical causes of this phenomenon and summarizes the economic and environmentally friendly uses of rice straw in the future. In addition, it points out that policy failures in the management of straw currently exist and that policies for integrated straw management are needed to improve the value chain in the supply and consumption of straw products; to enhance the effectively use of this resource and minimize environmental pollution.
\end{abstract}

\begin{abstract}
Hàng năm phát sinh khoảng 40-60 triệu tấn rơm sau thu hoạch ở Việt Nam. Mặc dù được coi là tài nguyên tái tạo và hàng hóa kinh tế, song rơm vẫn bị đốt bỏ ở ngoài ruộng do không còn nhu cầu nhiều cho đun nấu, lợp mái nhà và chăn nuôi như trước những năm 1990. Tình hình phát triển kinh tế chung của đất nước và khu vực nông thôn đãa làm thay đổi tất cả thói quen dùng rơm rạ trước đây. Bài báo này phân tích một cảnh tổng quan những nguyên nhân kinh tế - xã hội và kỹ thuật dẫn đến hiện tượng này, tổng hợp những khả năng sử dụng kinh tế và thân thiện môi trường của rơm rạ trong tương lai. Ngoài ra chi ra những thất bại về chính sách trong quản lý rợm rạ hiện nay và cần có các chính sách quản lý tổng hợp rơm rạ để nâng cao chuỗi giá trị trong cung ứng và tiêu thụ các sản phẩm rơm rạ, tăng cường việc sử dụng có hiệu quả tài nguyên này và giảm thiểu ô nhiếm môi trường.
\end{abstract}

Keywords: rice straw management, economic mechanism and policies, supply chain value

\section{Introduction}

Water rice is growing in the three main regions of the country: the Red River Delta, North and South Central Coastal regions and Mekong River Delta (MRD, known as the "Rice Bowl of Vietnam"). Rice plays a very important role to ensure national food security, contributing about 15\% to agricultural exports (Thai, 2018). The total area of three rice crops in 1990 was 6 million hectares with a total output of 7.8 million tons; after nearly 30 years, the area increased only 1.3 times, but production increased 5.4 times (in 2016/2017: 7.7 million hectares and 42.7 million tons) (Nguyen, 2017). From this, about 40-60 million tons of straw are generated (the coefficient of rice/straw depends on the type of rice and fluctuates between $1.01 \div 1.42$, according to Tran et al., 2014). Rice straw includes the stem and stubble (hereafter, both together straw), which is considered as renewable resource and economic good. In the industrialized countries, the straw is used for many economic purposes (non-energy and energy). In many developing countries, postharvest straw burning is a recurring phenomenon. Yang et al. (2014) reported that the average rates of burning wheat, rape and maize straw reached 65.5\%, 75.8\% and 57.3\% in Anhui province in the eastern region of China. In Vietnam, the situation has been similar for many years, causing environmental pollution and other ecological consequences. The aim of the article is to investigate and discuss the causes of this phenomenon, especially regarding the existence of potential problems in the straw value chain. In addition, the paper discusses policies needed to promote the use of straw more economically and environmentally friendly instead of burning it.

This paper attempts to analyse the past and current situation of postharvest rice straw use in Vietnam in terms of socio-economic and technical dimensions, and to present the policy failures in this area. The right policy in 
rice straw management is necessary. The data used in this paper are obtained from the General Statistics Office of Vietnam, from World Bank and other sources mentioned in the list of references. In addition, a small farmer survey in Yen Khanh district (Ninh Binh province) and in An Giang province was conducted by using the in-depth interview and observation. Different methodologies for the analysis are used.

\section{Change of rice straw use in Vietnam since 1990s}

Although the heat value of straw is much lower than petroleum (rice straw: $13.5 \mathrm{MJ} / \mathrm{kg}$, rice husk: $14.2 \mathrm{MJ} / \mathrm{kg}$, in comparison to petroleum/gasoline: 44-46 MJ/kg, according to the World Nuclear Organization, www.worldnuclear.org), most of the rice straw was used as an important burning material in rural areas. Additionally, a small part was used for cattle feeding, for covering the clay houses, for composting to obtain organic fertilizer and others. However, after 1995/1996, the traditional use of rice straw began to change. Gradually, the household use of electric kettles and then of rice cookers increased in rural areas. Since rural households still need to make home-made feeding for pigs, the cooking material always consisted of a combination of straw, wood, honeycomb coal, electricity and natural gas. After 2000, small domestic pig farming was no longer economical and the feed industry systematically replaced home-fed feeding so that straw use was phased out. The following statistics and facts will illustrate the situation above:

a) Technical conditions: The electricity supply has been much better than before since the commissioning of Hoa Binh hydroelectric power plant (producing hydroelectricity from 5.4 TWh in 1990 to 70.2 TWh in 2017, a growth rate per annum of $10.6 \%)$. The consumption of primary energy in 1965 was 2.5 million tonnes oil equivalent and increased to 6.5 million in 1990 and 75.3 million in 2017 (BP, 2019). The energy consumption per capita has increased rapidly from 297,226 kg oil equivalent per capita in 1971 to 654,963 in 2013 (World Bank, 2014). In addition, since the late 1990s, the prices for home appliances such as rice cookers, electric kettles, electric stoves, gas stoves which are imported from China and manufactured in Vietnam, have dropped rapidly.

b) Change of socio-economic conditions: The national gross domestic product (GDP) per capita increased from 361 USD/head in 2000 to 2,171 USD/person in 2017
(Nguyen, 2017). Next, with the success of rural poverty reduction policies, the poverty rate has plummeted and the standard of living in rural areas has improved. In addition, the traditional view of the kitchen and the gender has changed fundamentally: the kitchen is the space not only for women, but also for men. But the state of the kitchen needs to be improved. At the same time the movement/revolution "modernization of the kitchen" is widespread, the farmers want to show their standard of living in the village community by the picture of the kitchen, also kitchen with "modern" equipment. Therefore, gradually more and more rice straws are replaced mainly by honeycomb, then by natural gas and/or electricity. According to Pirelli et al., 2018. firewood consumption decreased in Vietnam although 34.1\% of Vietnamese households are still using wood and straw for cooking and only $4.7 \%$ of rural households use coal.

c) Agricultural and rural development policy of the state: (c1) The tendency of transition from land-based farming to intensive agriculture with the aid of chemical fertilizers so that organic fertilizer is almost completely replaced (chemical fertilizer used for rice production in Vietnam increased from $98 \mathrm{~kg}$ NPK/ha in 1990 and now to 400-500 kg NPK/ha according to Nguyen, 2014); (c2) The movement of "Eradicating the cottages with rice straw roof" has been successful in the whole country, followed by cementing and concreting rural areas, especially the development of rural infrastructure when implementing the National Target Program on New Rural since 2010; (c3) Biogas program for Vietnam's livestock sector in the first phase (2003-2006), second phase (2007-2012) and continues to renew, leading to biogas cookers replacing most straw and rice husk stoves; (c4) The use of natural gas stoves increased due to the public and private retail gas distribution network extending in rural areas; (c5) The fodder of cows and buffaloes has changed, the raw material (e.g. rice straw) has been reduced and the mixing feed increased to produce more meat and milk, rather than generating power; (c6) Expanding rural electrification, specifically $70-80 \%$ of households were using electricity in the period 1980-1990, and 98.88\% in 2010

Figure 1 shows some of the factors selected to demonstrate the impact on postharvest straw use. In general, there has been a big change in the last 30 years. Up to now, most farmers burn the straw in the fields, causing environmental consequences, affecting ecosystems and climate as well as wasting resources. So where should the state policy start to overcome this problem? 


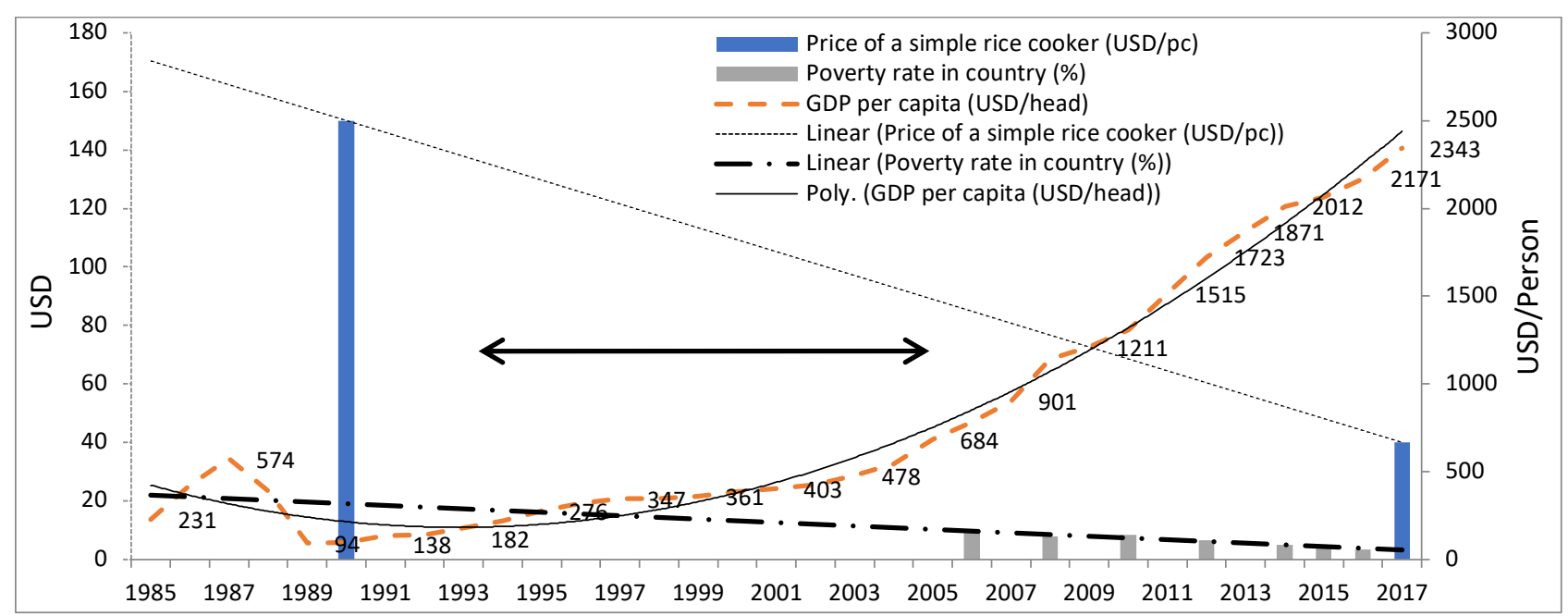

Figure 1. Assume the period in using straw: from cooking to field burning (1994-2004) by analysing several relevant factors (adapted from Nguyen and $\mathrm{Vu}, 2018$ )

\section{Brief description of straw utilization}

Figure 2 presents the definition of straw and stubble (a), the major components of rice straw (b) and its potential use (c). Concerning Figure 2c), the rice straw can be used for different purposes (in/off-field, with/without energy utilization). Next, we will review some of the possibilities of using straw.

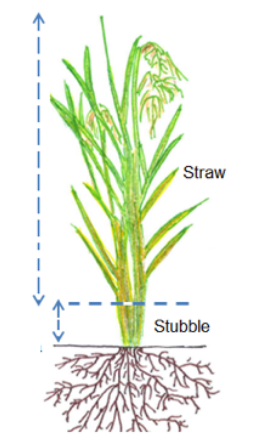

Fig. a) Rice straw and stubble

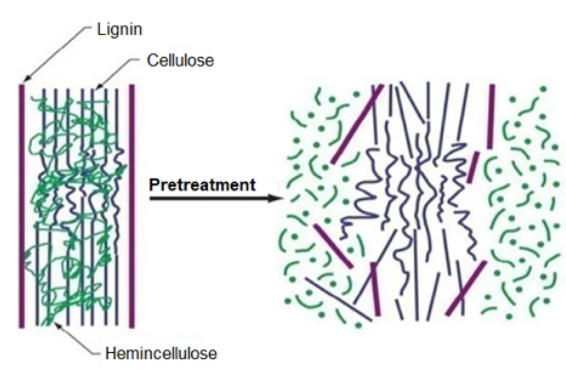

Fig. b) Major components of lignocellulosic biomass (source: rice knowledge bank)

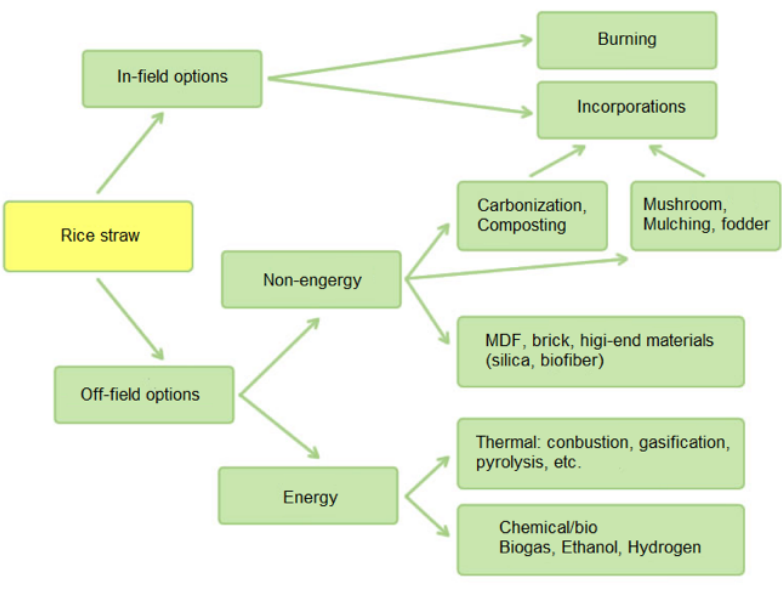

Fig. c) Options for rice straw management and use (source: rice knowledge bank)

Figure 2. a) Definition of straw and stubble, b) major components of lignocellulosic biomass and c) use options for rice straw (source: Rice Knowledge Bank, 2019b)

\subsection{In-field options}

\subsubsection{Soil incorporation and humus supply}

VanKessel and Horwath (2001) conducted a long-term study to investigate different methods of managing the rice straw problem in California (USA). The methods of disposal included four techniques: burning, soil incorporation, rolling, and baling \& removing the straw. Each of these methods was compared with and without winter flooding, resulting in total of eight different methods (burn, incorporate, roll, bale \& remove, burn \& flood, incorporate \& flood, roll \& flood, bale/remove \& flood). The evaluation criteria are soil fertility and several environmental impacts. The soil incorporation or rolling combined with winter flooding were shown to result in the fastest straw decomposition rates and most significant improvements in soil fertility. After five years, the nitrogen fertilizer requirements were reduced. The air quality impacts are minimized compared to burning for all the non-burn options. But the burning of rice straw in the field is capable of removing some diseases that Webster and Cintas (2001) studied in California. Under continuous rice cropping, open field burning has been the primary means of rice residue disposal and of minimizing the carry over inoculum of Sclerotium oryzae (Catt.), the cause of stem rot of rice. A farmer survey by Vu (2018) in Yen Khanh district (Ninh Binh province) confirmed that: (1) Incorporation of stubble in Yen Khanh is hardly feasible because the time between two crop seasons is too short. If the stubble is not flooded, it is difficult to decompose it. In addition, it makes tillage very difficult and causes high soil acidity; (2) Burning rice straw in the field reduces diseases and pests as well weeds spread from the previous crop to the next one. Now 
farmers use a lot of pesticide and herbicide so that this relationship is not relevant. In April 2009, a team from the SUVALIG research project (SUVALIG, 2018) visited the field in An Giang province in MRD and saw how fast the rice was harvested, and then there was immediate burning of rice straw and after that the ground preparation. Rice straw burning occurs on large area immediately after the harvest.

\subsubsection{Burning}

According to Dang et. al (2011), rice straw has different chemical components: humidity $7.08 \%$, cellulose $42.41 \%$, hemicellulose 12.65\%, lignin 18.62\%, extraction compounds $6.48 \%$, and ash $12.76 \%$. The ash composition is: $\mathrm{SiO}_{2} 72,593 \%, \mathrm{~K} 2.636 \%, \mathrm{Na} 0.369 \%$ and other elements $24.402 \%$ and the elemental composition in straw (\% of dry mass) is: C 673.113, H 58.454, O 254.134, N 14.299 and S 0.0000 .

When burning these compounds, greenhouse gas emissions include: 0.7-4.1 $\mathrm{g} \mathrm{CH}_{4}$ and 0.057-0.19 g N $2 \mathrm{O} / \mathrm{kg}$ of dry straw and other air pollutant emissions such as $\mathrm{SO}_{2}$, $\mathrm{NOx}, \mathrm{HCl}$ and to some extent dioxin and furan. Burning straw is also an important source of aerosol particles such as coarse dust particles (PM10) and fine particles (PM2.5), affecting the regional air quality and the earth's radiation budget. In addition, there are many studies/articles, for example, Nguyen et. al (2015) who reported the technical, economic and environmental assessment of rice straw harvesting methods, or Tran et. al (2014) who estimated the calculation and measures of rice straw treatment in some provinces of MRD.

\subsection{Off-field options}

\subsubsection{Non-energy use}

a1) Mushroom production: The Ministry of Agriculture and Rural Development (MARD) in Vietnam aims at developing the mushroom industry in Vietnam to reach 1 million tons by 2020 and to create jobs for 1 million workers from mushroom production. According to the Department of Crop Production of MARD, Vietnam is cultivating 16 types of mushrooms with an annual production of about 250,000 tons of fresh mushrooms, leading to an export turnover of about 25-30 million USD/year. Specifically, the straw mushroom production is 64,500 tons, ear mushroom is 120,000 tons, and oyster mushroom is
60,000 tons. About $90 \%$ of straw mushroom is produced in the MRD, concentrated in the provinces of Soc Trang, An Giang, Can Tho, Dong Thap and Vinh Long. The major obstacles to the development of straw mushroom production are: (1) Straw collection is still difficult. Combine harvester makes straw to fall on the field and the farmers must collect it by hand. There is a lack of straw baler machines as well as transport machines; (2) Problem with the output for mushrooms. It is estimated that $80 \%$ of the production is consumed domestically and $20 \%$ is exported. Straw mushrooms are exported in the form of in-salt, canned or dried. Canned and dried are not favoured by the market. Fresh mushrooms are difficult to export due to the storage/preservation; (3) Obstacles to cultivating mushrooms, especially that straw mushrooms are susceptible to disease.

a2) Animal feed (fodder): Although mechanization in agriculture has increased in recent years, cattle and buffaloes are still abundant and serve other purposes. Feed costs for cattle can account for more than 50\% of the total cost. The area of grass growing in Vietnam is reduced, so cattle owners still have to rely on straw, although the nutrients of straw are much lower than grass. The demand for rice straw for cattle is about 1 ton/year/animal with the number of cattle and buffaloes in the whole country in 2017 being 2.5 million buffalos and 5.7 million cows.

According to Nguyen (2018), straw is currently being purchased to produce a fair amount of fodder. The straw supply is not enough, so we have to import straw at the price of 400 USD/ton. For example, the company $\mathrm{TH}$ Truemilk buys straw at the price of about 3.2 million VND/ton. It is estimated that $40 \%$ of the purchased rice straw in the value chain in Hau Giang province is used as animal feed.

a3) Compost: According to the author's estimation, the use of this organic fertilizer will save 20 to $30 \%$ of production costs. In the coming years, when the market requires more eco-products, the organic fertilizer made from rice straw would become important. The main problem is replicating the model and restarting composting in the countryside because it has been forgotten for the past 20 years when chemical fertilizers are too cheap. The results of our big survey in three communes in Danang city in 2013 concerning the rural solid waste management and composting in frame of the ECUD project (GIZ, 2018) confirm this conclusion. 


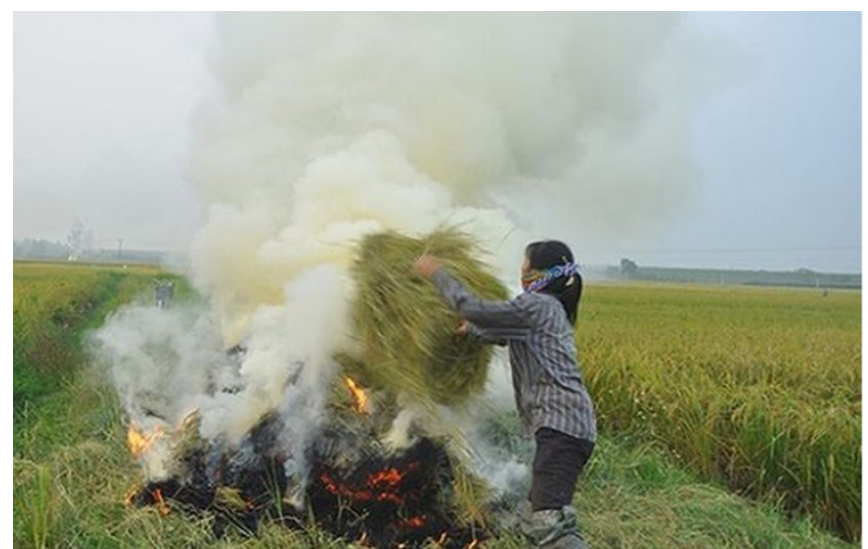

a) Burning in the field

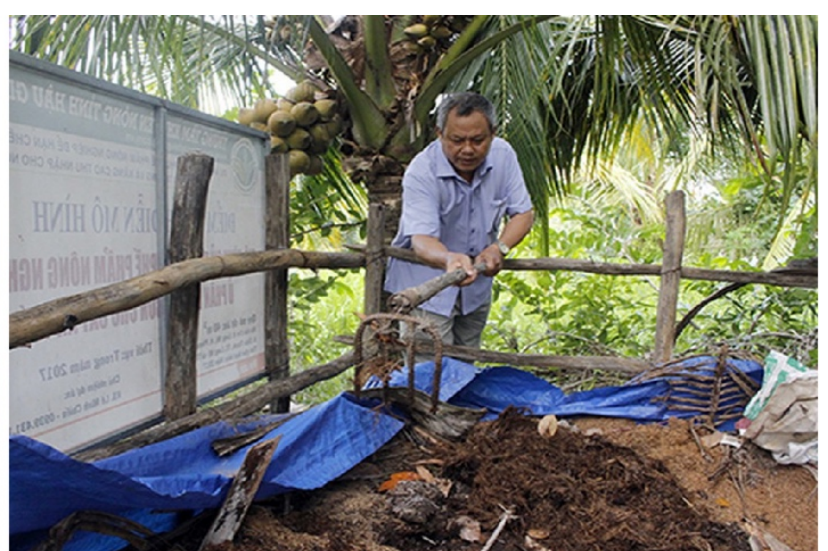

b) Composting

Figure 3. Situation of field burning of straw (source: Nghia, 2018) and replication of straw composting model in Hau Giang province in MRD (source: Le, 2018)

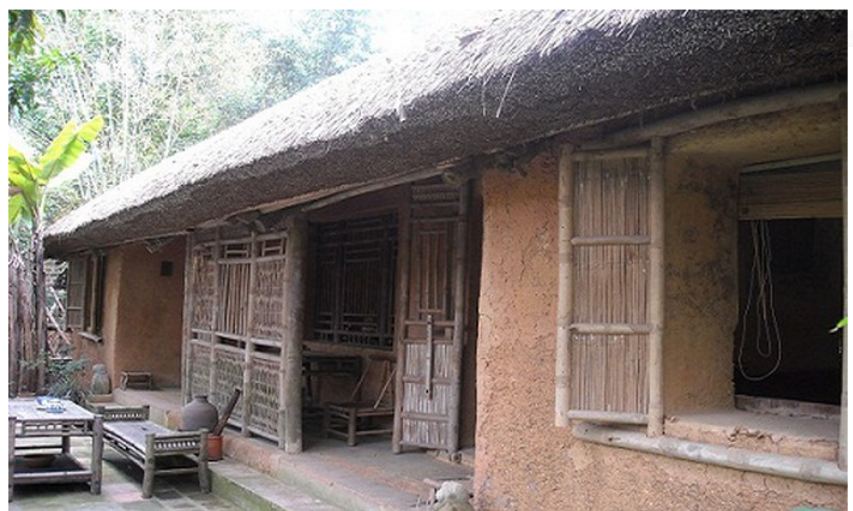

a) Old farmer house of straw and clay

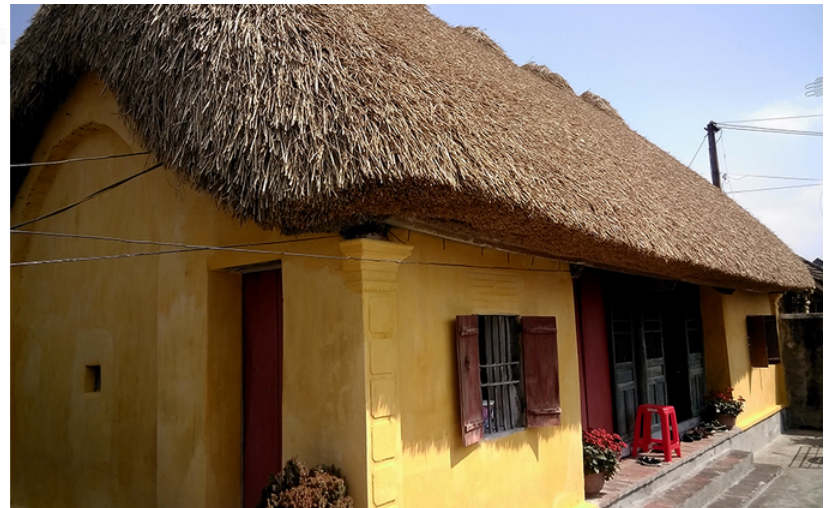

b) Modern house of straw and clay

Figure 4. House of straw and clay - past (source photo left: Bao Moi (2017) and present (source photo right: Manh, 2016)

a4) Straw for the paper industry: Straw is considered a promising material source for the paper industry. The manual paper making from straw appears quite early in Asia, typically in Burma and northern Thailand. The advantages of rice straw are: (i) the lignin content is lower than that of wood so less energy is needed in the manufacture process; (ii) it consumes less chemicals and energy during cooking; (iii) the straw fibre is tough so provides mechanical strength to the paper powder; and (iv) collecting the straw is easy, so raw materials are abundant. The disadvantages are: (i) the high silicon content makes it difficult to recover the chemicals and it wears out the equipment; (ii) high transport costs for straw bales; (iii) the pulp performance is not high; (iv) high-volume waterretaining in straw fibre is also a problem in separating water from fibre during paper making. Currently in Vietnam, there is no factory producing paper from straw, so there is no demand.

a5) Medium-density fibreboard (MDF), bricks, high-end materials (silica, biofibre): Some attempts to extract and/or exploit certain ingredients in the rice straw were indicated in the study by Guzmán et al. (2015) who noted: "It is concluded that rice straw ash is a new alternative ceramic raw material that can be used as a replacement for the fluxing (mainly feldspar) and inert (quartz) materials that are used in the production of triaxial ceramics, including those used in some construction materials (tiles)". In the frame of SUVALIG project, a group of Vietnamese and German researchers conduct their research in a similar research direction on the exploitation of chemical components for industrial use (SUVALIG, 2018).

a6) Straw for building: Before the 1990s in rural area of Northern Vietnam, there were many houses built with straw mixed clay. Then this kind of house was replaced with a simple brick house. In the future, it is possible to promote the construction of such cheap houses with straw for low-income households. This requires further research in the building materials industry (see Fig. 4).

a7) others: For the packaging of agricultural products, flooring in the cowshed, production of heat-resistant panels, handicrafts.

\subsubsection{Energy use}

Straw can be used for thermal combustion and gasification. Currently, second generation biofuels are prioritized for research and use because they will almost certainly not affect food prices and ensure global food security. Biomass such as rice straw, cereal stalks and other agricultural by-products generated annually in the world reach about half a billion tons, of which Asia 
accounts for 92\%. In addition, rice straw is also called 'pressed wood'. After crushing, the straw is dried and pressed under high pressure into uniformly shaped blocks. This is considered a renewable energy source and

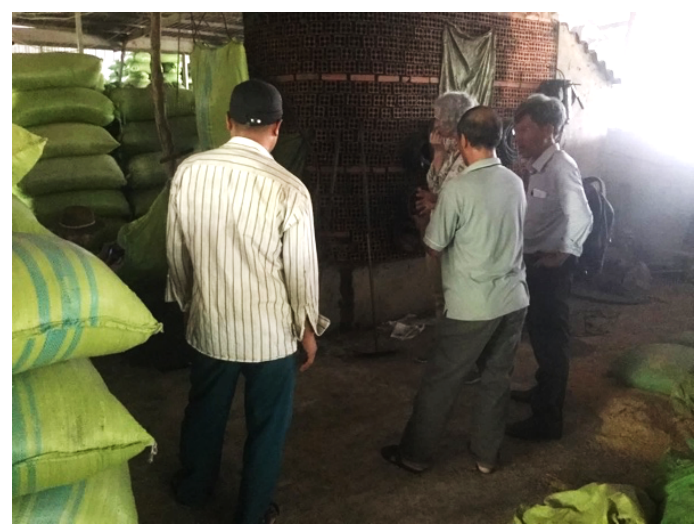

a) SUVALIG team visiting a small biochar manufacturing and heat recovery plant for drying rice in Dong Nai Province is a cost effective alternative to other products such as coal, oil and gas. Some companies in Vietnam have developed in this direction (Fig. 5).

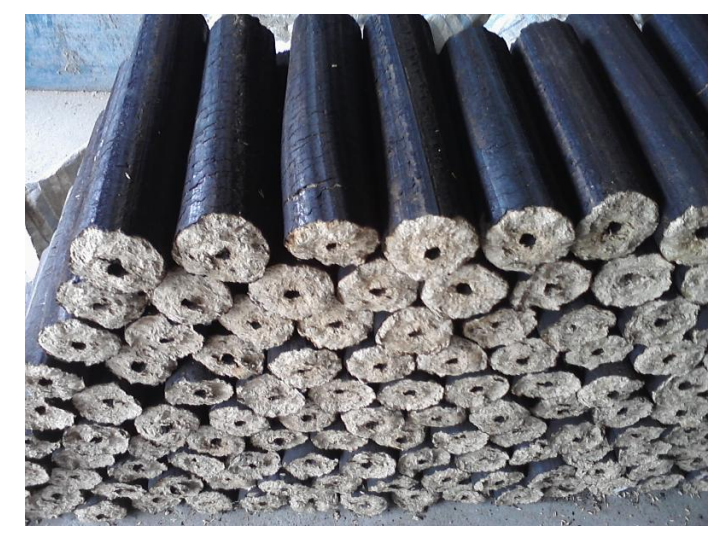

b) Production of rice straw wood in a company in Hai Phong city

Figure 5. Production of biochar - photo left (SUVALIG, 2018) and rice straw brickets - photo right (Khanh Minh Import Export Trading Co., Ltd. (2009))

\section{Main policies for straw management in Vietnam}

\subsection{The supply and value chain of straw in Vietnam}

a) The supply and value chain of straw in Vietnam are presented in Figure 6. In this value chain, three stakeholders play important role: the government, the farmers and/or the cooperatives generating rice straw, and the industry, as straw consumer (enterprise, factory). The government creates a legal basis and the straw market can regulate itself. According to Nguyen and Gummert (2017), the straw market model in the MRD provinces like Hau Giang is well established and functioning. The big straw customers are mainly the breeding and mushroom farms. In the period of 2013-2016, the price of straw has almost doubled from 260,000 VND to 520,000 VND/ha due to the strong development of mechanization technology in the collection. The selling price for straw in the field has dropped about 35\% and the market price for straw bale dropped by $17 \%$. The technology of the straw bale machine has changed dramatically over the last five years, resulting in a significant reduction of labour costs. It can be said that the market will work well if the output is at an acceptable price. Good prices increase the collection and increase the investment in collection and transportation equipment.

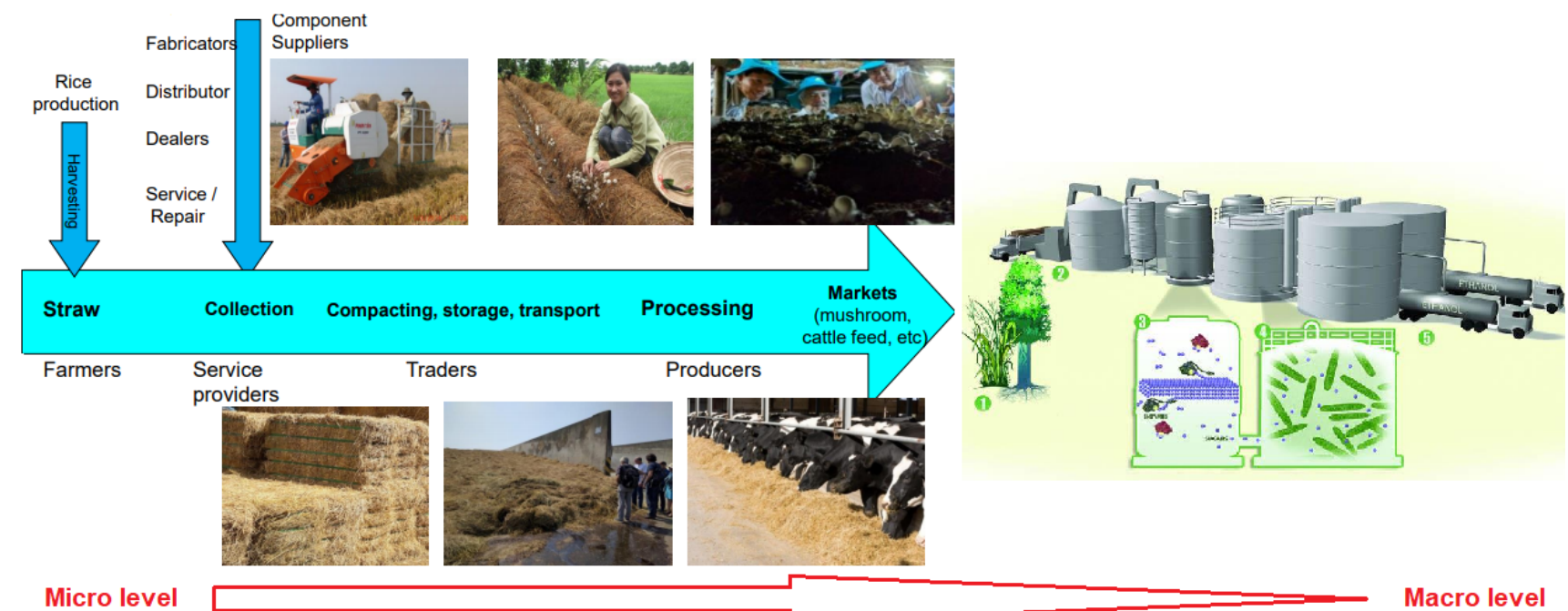

Figure 6. The supply chain and value chain of rice straw in Vietnam (Nguyen and Gummert, 2017) 


\subsection{Discussion on the international and national policies}

b1) International trade: Green barriers can produce both positive and negative impacts on the international trade. The positive effect is that the Vietnamese agriculture must switch to clean and organic production, with good management of post-harvest straw for environmentally friendly use and a circular economy (increased use of organic fertilizers such as rice straw composting) playing an important role. Recently, the European Union - Vietnam Free Trade Agreement (EVFTA) was signed between the EU and Vietnam. Under others, the agricultural products, seafood, sugar, rice, honey, processed agricultural products, wood products, textiles, footwear, furniture and the automobile industry will enjoy preferential treatment from Europe (Viet Nam News, 2019). Following EVFTA, Vietnam's agricultural products have more export opportunities to the $\mathrm{EU}$ if they meet the EU requirements.

b2) National policies: The Government was assigned with the task of disseminating and enforcing political and legal bases as well as national economic policies and development programs for farmers and industry. So far, the government has focused more on developing the national economy based on agricultural and rural development. For example, the Decree 109/2018/ND-CP "Organic agriculture" dated 29.08.2018 providing preferential terms for small enterprises, cooperatives, farms and farmer households engaged in organic agriculture. According to this decree, the government will fund all organic product certification costs and the costs of verifying areas eligible for organic production. This means that a lot organic waste is needed in agricultural production and the treatment of straw is an important basis.

Next, the Circular guidance on methods for saving and efficiently using the energy in agricultural production issued by MARD and dated 29.06.2018 provides regulation in terms of collection and re-use of agricultural byproducts such as rice straw, stubble, husk, bagasse, ... as input materials for other industries such as production of mushroom production, fertilizer, animal feed, bio-fuel and biomass (Chapter 2, Article 3).

In order to ensure the energy security, protect the environment and promote rural economic development in remote areas, on 20.11.2007, the Prime Minister approved the program "Bio Fuel Development" to 2015, vision 2025". The project includes the activities of governmental agencies and enterprises to build a roadmap for the use of biofuels in Vietnam, the legal framework and policies to encourage production, as well as building testing models. The focus is on the experimental production and distribution of biofuels as well as the investment projects of the Government to develop biofuels up to 2025. Until now, the national program of "Biofuel development in Vietnam" was always the way to go. In the future, Vietnam needs to expand the production capacity of the biofuel plants as well as build medium-scale bio refinery factories in the important rice regions to use the by-products such as rice straw, rice husks, corncobs and others.

b3) Industry (relevant producers or straw consumers): measures to encourage investment in the development of energy, biogas and biofuel production from straw. The price of these types of energy must cover production costs and be profitable for companies. Until now, there are three ethanol plants (based mainly on cassava) of the Ministry of Industry and Trade (MOIT) but still under construction and not being able to operate (Quang Ngai, Binh Phuoc and Phu Tho Biofuel Production Plants). After nearly 18 years from the approval of the program "Biofuel development in Vietnam", the Phu Tho ethanol factory may go bankrupt due to its unfavourable location and inefficient business model (Ha, 2018). In addition, the industry must support the production of straw collectors or baler machines, as well as transport machines, at appropriate costs. A straw market should be created whose prices are determined by the pressure of the policy and the legal basis of the government and the own value of the straw (Figure 7).

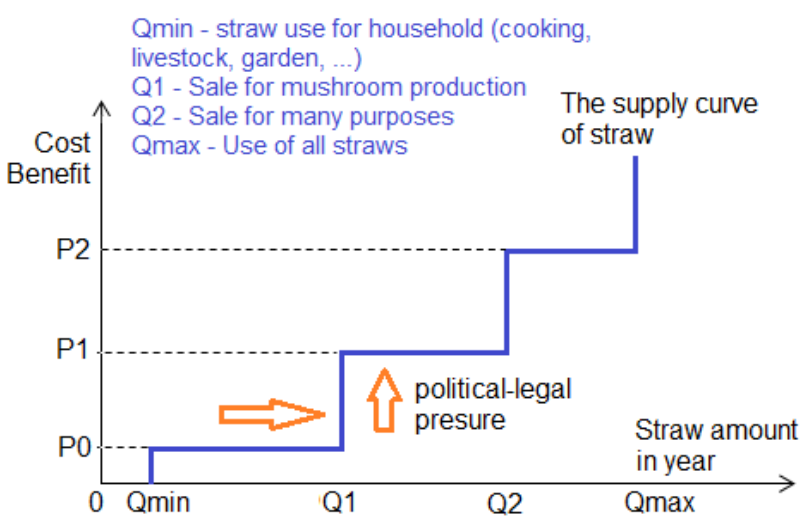

Figure 7. The supply curve of rice straw and the role of government for the functioning the market

b4) Farmer and/or cooperative: for farmers and cooperatives, the government has issued legal documents such as ban, recommendations and instructions not to burn or reduce burning of rice straw at all levels, from the central to local level. However, it is also difficult to enforce this because all are administrative documents. As shown in Figure 7, the farmers' major consumption of rice straw must be encouraged and create a straw market at a price that is suitable to offset the collection and profit margins.

\section{Conclusion}

Rice straw is one of the least valuable agricultural byproducts, especially in rice exporting countries, as in Vietnam. The use of post-harvest straw has changed substantially over the past 30 years, but the government's policy has slowed down, leading to widespread burning in the field despite being considered a resource and economic commodity. In this paper, the role of different 
stakeholders in straw supply and value chain is analysed. To solve this problem thoroughly, economically and environmentally as well as in terms of climate protection is to invest in building biorefinery industries/factories in key rice areas in the form of state or private investment, followed by establishment of a good straw market. In order to do that, it is necessary to have good strategies, policies, legal bases and economic mechanisms that can be learned from other countries with much experience in this field.

\section{References}

[1] Bao Moi (2017) Bui looked back at the old houses. Retrieved on July 16, 2019 from: https://baomoi.com/bui-ngui-ngam-lai-nhung-ngoinha-dat-thoi-xa-xua/c/21606224.epi (in Vietnamese).

[2] BP (2019). Statistical Review of World Energy - all data 1965 - 2018. Retrieved on July 16, 2019 from: https://www.bp.com/content/dam/bp/businesssites/en/global/corporate/xlsx/energyeconomics/statistical-review/bp-stats-review-2019all-data.xIsx.

[3] Dang, T.P., Tran, T.K.H., Vu, A.T. (2011). Using Vietnam straw to produce bio-oil. Retrieved on July 16, 2019, from: http://www.vusta.vn/vi/news/Thong-tin-Sukien-Thanh-tuu-KH-CN/Su-dung-rom-ra-Viet-Namde-san-xuat-dau-sinh-hoc-bio-oil-37988.html (in Vietnamese).

[4] GIZ (2012). Project "Environmentally and climatefriendly urban development in Da Nang (ECUD)". Deutsche Gesellschaft für Internationale Zusammenarbeit (GIZ), GmbH. Retrieved on July 16, 2019 from: http://resilient-cities.iclei.org/fileadmin /sites/resilient-cities/files/Resilient_Cities_2012/ Program_Updates/Presentation/B/B1/RC_2012_3_Pr esentation_Schweikhardt.pdf

[5] Guzmán, A., Delvasto, S., Sánchez, E. (2015). Valorization of rice straw waste: an alternative ceramic raw material, Cerâmica, 61, 126-136. http://dx.doi.org/10.1590/036669132015613571888.

[6] Ha, V. (2018). Phu Tho ethanol may go bankrupt. Retrieved on July 16, 2019 from: https://www.vir.com.vn/phu-tho-ethanol-may-gobankrupt-63460.html.

[7] Khanh Minh Import Export Trading Co., Ltd. (2009). Super heat straw-wood. Retrieved on July 16, 2019 from: http://khanhminhhn.com.vn/vi/Thong-Tin-SanPham.aspx?id=77\&idn=2009 (in Vietnamese).

[8] Le, H. (2018). Hau Giang: replicate the model of composting straw as organic fertilizer. Retrieved on July 16, 2019 from: https://baomoi.com/hau-giang-senhan-rong-mo-hinh-u-rom-lam-phan-huuco/c/26651845.epi (in Vietnamese).

[9] Luc, T.L. (2017). Effectiveness of the model
"Incubation and treatment of straw into bio-organic fertilizers". Retrieved on July 16, 2019 from: http://yenthe.vn/kinh-te/hieu-qua-tu-mo-hinh-u-xuly-rom-thanh-phan-huu-co-sinh-hoc.htm (in Vietnamese).

[10] Manh, Q. (2016). The house of rice straw in the capital of rice. Retrieved on July 16, 2019 from: https://vnexpress.net/du-lich/nhung-ngoi-nha-maira-o-thu-phu-gao-tam-3354611.html (in Vietnamese).

[11] Münch, J. (2008). Nachhaltig nutzbares Getreidestroh in Deutschland, Positionspapier. IFEU - Institut für Energie- und Umweltforschung Heidelberg $\mathrm{GmbH}$, Germany.

[12] Nghia, M. (2018). Mobilizing people not to burn straw in the field. Retrieved on July 16, 2019 from: https://baomoi.com/van-dong-nguoi-dan-khong-dotrom-ra-tai-dong-ruong/c/27065703.epi Vietnamese)

[13] Nguyen T.D. (2014). Use of fertilizers and pesticides in agriculture in Vietnam - discussion on ecological and sustainable economic aspects. Journal of Irrigation and Environmental Science and Technology, 46, 108116 (in Vietnamese).

[14] Nguyen, T.D., Vu, T.H.N. (2018). General management of harvesting. Hydrology and Environment Engineering Science, 63, 135-141 (in Vietnamese).

[15] Nguyen, T.H. (2017). An Overview of Agricultural Pollution in Vietnam: The Crops Sector. Prepared for the World Bank, Washington, DC.

[16] Nguyen, T.H. (2018). Improving the efficiency of using straw to reduce environmental pollution. Vietnam Environment Administration Magazine, 6, 32-34 (in Vietnamese).

[17] Nguyen, T.N., Nguyen, D.C., Hau, D.H., Nguyen, V.H., Gummert, M. (2015). Technical, economic and environmental evaluation on mechanical rice straw gathering method, Journal of Environmental Science and Engineering B 4, 614-619. http://dx.doi.org/10.17265/2162-5263/2015.11.006.

[18] Nguyen, V.H., Gummert, M. (2017). Postharvest and by-product management for sustainable rice production value chain. Presentation at the Workshop "Investments in Energy Sustainable Technologies in the Agrifood Sector (INVESTA)", FAO, Rome, November 23-24, 2017.

[19] Nguyen, V.H., Topno, S., Balingbing, C., Nguyen, V.C.N., Röder, M., Quilty, J., Jamieson, C., Thornley, P., Gummert, M. (2016). Generating a positive energy balance from using rice straw for anaerobic digestion. Energy Reports, 2, 117-122.

[20] Pirelli, T., Rossi, A., Miller, C. (2018). Sustainability of biogas and cassava-based ethanol value chain in Vietnam - Results and recommendations from the implementation of the Global Bioenergy Partnership 
indicators. Working paper 69, FAO, Rome, Italy.

[21] Rice Knowledge Bank (2019a). In-field rice straw management. Retrieved on July 16, 2019 from: http://www.knowledgebank.irri.org/step-by-stepproduction/postharvest/rice-by-products/ricestraw/in-field-rice-straw-management.

[22] Rice Knowledge Bank (2019b). Rice straw. Retrieved on July 16, 2019 from: http://www.knowledgebank.irri.org/step-by-stepproduction/postharvest/rice-by-products/rice-straw.

[23] Rogall, H. (2019). Sustainable economics - The basis of sustainable economic development. Construction Publishing House (in Vietnamese, original translation from German).

[24] SUVALIG (2018). Joint German-Vietnamese Research Project "Sustainable biorefinery concept focusing valorization and cascading of Vietnamese lignocellulose waste for rural communities", Universität Rostock, Germany. Retrieved on July 16, 2019 from: https://www.auf.uni-rostock.de/ professuren/a-g/abfall-und-stoffstromwirtschaft/ forschung/projekte/suvalig/ (in German).

[25] Thai, B. (2018). Export of agricultural products: vegetables, cashew nuts - increasing, rice, rubber decreasing. Retrieved on July 16, 2019 from: http://www.vietpress.vn/xuat-khau-nong-san-rauqua-hat-dieu-len-dinh-gao-cao-su-tut-hangd67173.html (in Vietnamese).

[26] Tran, S.N., Nguyen, T.H.N., Nguyen, H.C., Nguyen, V.C.N., Le, H.V., Ingvorsen, K. (2014). To quantify the seasonal rice straw and its use in different provinces in the Vietnamese Mekong Delta. Science Journal of
Can Tho University. Part A: Natural Science, Technology and Environment. 32, 87-93 (in Vietnamese with abstract in English).

[27] VanKessel, C., Horwath, W. (2001). Managing rice straw: Research shows many advantages of winter flooding. In: Proceedings of "Rice straw management update", p. 4-8, University California David. USA, March 6, 2011.

[28] Viet Nam News (2019). EVFTA ensures benefits for both Việt Nam and EU". Retrieved on July 16, 2019 from: http://vietnamnews.vn/economy/521857/ evfta-ensures-benefits-for-both-viet-nam-andeu.html\#H7OUDmfKqQ3i8Loi.99.

[29] Vu, T.H.N. (2018). Strengthening the management of straw sources in agricultural production in Yen Khanh district, Ninh Binh province. Master thesis, Thuy loi University, Vietnam (in Vietnamese).

[30] Webster, R.K., Cintas, N.A. (2001). Effects of various methods of straw management on Sclerotium oryzae inoculum, stemrot severity, and yield of rice in California. In: Proceedings of "Rice straw management update", p. 9-17, University California David. USA, March 6, 2011.

[31] World Bank (2014). Energy use (kg of oil equivalent per capita). Vietnam. Retrieved on July 16, 2019 from: https://data.worldbank.org/indicator/EG.USE.PCAP.K G.OE?locations=VN

[32] Yang, Y., Wang, X., Zhang, T., Li, D. (2014). Utilization of crop straw resources in Anhui province, eastern China. Bulgarian Journal of Agricultural Science, 20(6), 1302-1310. 